\title{
INTIMA-MEDIA THICKNESS OF THE COMMON CAROTID ARTERY AND LDL-R DEFECT IN ASYMPTOMATIC SEVERE HYPERCHOLESTE- ROLEMIA
}

\author{
Lyudmila G. Vladimirova-Kitova, \\ Clinic of Cardiology, \\ Medical University, Plovdiv, Bulgaria
}

\begin{abstract}
The data on the examination of early vascular alterations in carriers of molecular defects of the LDL-R in comparison to non-carriers with severe hypercholesterolemia are controversial. Aim: To examine the difference between patients with severe hypercholesterolemia, who are carriers and non-carriers of LDL-R defective gene, with respect to their structural (intima-media thickness of carotid artery) characteristics of arterial wall. A total of 60 hypercholesterolemic patients were enrolled. Biochemistry parameters were examined by routine methods. Determination of intima-media thickness of common carotid artery was performed with Hewlett Packard Sonos 5 500, using automated computer software MedicaSoft. IMT.lab. Results: There was no significant difference between the groups with respect to total cholesterol, LDL, HDL, triglycerides. We were founded a significantly higher carotid IMT in the carriers versus non-carriers. This significant difference was confirmed after adjustment for age and gender. Conclusion: Our data demonstrate that carriers of the LDL-R defective gene have a higher carotid IMT than non-carriers, whereas no difference between the groups was found with respect to the level of lipid parameters.
\end{abstract}

Key words: hypercholesterolemia, low-density lipoprotein receptor gene, intima-media thickness, carotis artery

\section{INTRODUCTION}

Familial hypercholesterolemia (FH) can be due to different genetic defects in the LDL-R which lead to impaired LDL clearance (1). Severe hypercholesterolemia and family history of early vascular diseases are important determinants of the development of the intima-media complex of the common carotid artery (IMT CCA) in FH (2-4). The data on the examination of early vascular structural alterations (by measurement of the IMT CCA) in carriers of molecular defects of the LDL-R in comparison to non-carriers with severe hypercholesterolemia in the literature are controversial (4-10). Evidence on this issue could be used in developing the treatment algorithm of newly detected severe hypercholesterolemia. Most of the studies on severe FH are carried out in patients with manifested coronary artery disease (11-20), data about patients with asymptomatic FH are scarce (21-23).

\section{AIMS}

To examine the difference between patients with newly detected severe hypercholesterolemia, who are carriers and non-carriers of LDL-R defective gene, with respect to their structural (IMT CCA) characteristics of arterial wall.

\section{PATIENTS AND METHODS}

We included 60 (age over 16 years) patients with primary hypercholesterolemia, which met the Simon-Broome register criteria (24): 1 . Total cholesterol level above $7.5 \mathrm{mmol} /$ 1 in people over 16 years of age. 2. Tendon xanthomata in first or second degree relatives. 3. A myocardial infarction before age 60 in first degree relatives and before age 50 in second degree relatives. 4 . Total cholesterol above $7.0 \mathrm{mmol} /$ 1 in first or second degree relatives]. A diagnosis of definite $\mathrm{FH}$ requires meeting criteria 1 and 2. A diagnosis of possible FH requires meeting criteria 1 and 3 or 1 and 4 . As exclusion criteria we introduced most of the well known factors of endothelial dysfunction or influencing the latter striving to create pure model of hypercholesterolemia. The exclusion criteria's were presented in table 1 . 
Table 1. Exclusion criteria

1. Diabetes mellitus or impaired fasting glycemia - fasting blood glucose level $>5.6 \mathrm{mmol} / 11$.

2. Cigarette smoking.

3. Presence of clinical history, clinical and laboratory evidence of:

3.1. Coronary artery disease in all forms.

3.2. Cerebral vascular disease

3.3. Hypertension.

3.4. Chronic obstructive pulmonary disease, Bronchial asthma.

3.5. Chronic arterial insufficiency in the extremities - ankle-brachial index $<0.9$.

3.6. Chronic renal or hepatic diseases.

3.7. Systemic connective tissue disorders: Collagenosis, lupus, rheumatoidarthritis.

3.8. Neoplasia.

3.9. Acute or chronic inflammatory disorders requiring treatment.

4. Prolonged use (over the last 6 months or during the study) of nonsteroidal anti-inflammatorydrugs, hormonal drugs, psychotropic medication, drugs - fibrates, statins, and anti-oxidants.

4.1. Chronic alcohol or drug abuse.

According to whether there were or were not molecular defects, patients were assigned to two groups: carriers (11 patients, $18 \%$ ) and non-carriers (49 patients, $82 \%$ ).

Prior to the study procedures a written informed consent was obtained from hypercholesterolemic patients. The procedures used in this study were approved by the Ethics Committee at Medical University of Plovdiv.

All study subjects were assessed for family history of early-onset coronary artery disease, clinical history, medication use, anthropometric characteristics, cardiovascular risk factors and tendon xanthomas. All the patients are asymptomatic and they had not taken statins up to medical examination.

Laboratory tests were performed at the Central Clinical Laboratory of St George University Hospital, Plovdiv. The biochemical parameters of blood glucose, total cholesterol, triglycerides, high density lipoprotein cholesterol, urea, creatinine, and uric acid were measured using a biochemical analyzer Konelab 60i (Thermo Electron Co, USA). Determination of LDL-cholesterol was performed using a direct analysis and reagents from Thermo Electron Co KonelabTM (Finland). The "cholesterol-years" score is an estimate of the lifelong total vascular exposure to the profound hypercholesterolemia in these patients. This cholesterol-years score was calculated as follows - the total cholesterol concentration (in $\mathrm{mmol} / \mathrm{L}$ ) of each patient at the time of original diagnosis was multiplied by the age of the patient at diagnosis.

Molecular biological analysis. The present study included 60 DNA samples of FH patients of both genders. Samples of high-molecular DNA isolated from nuclear blood cells were used as material for the genetic analysis. The blood samples were withdrawn 30 min to 1 hour after meals in plastic tubes with EDTA anticoagulant. They were stored at $+4^{\circ} \mathrm{C}$ for 48 hours. The technique included several stages: 1 .
Isolation of DNA; 2. Amplification of a specific target of DNA fragment using polymerase chain reaction; 3 . A single strand conformation polymorphism SSCP analysis; 4. Direct sequencing. The R3500Q-mutation in the Apo-B gene was sought first (25). LDL-R gene mutation and polymorphism (and the promoter region), as large rearrangements, were then identified using denaturing gradient gel electrophoresis (26) and DNA sequecimg of the abnormal exon. When these analyses were negative, DNA was subjected to long-range polymerase chain reaction (PCR).

The measurement of IMT was conducted by the method of Pignoli et al. (27) MedicaSoft.IMT.Lab automated computer software was used to measure IMT CCA. The upper US demarcation line was defined as leading margin (intimamedia border), the lower line was defined as a distant margin (media-adventitia border). The leading line is important in the process of the automatic measurement. Using the left mouse button, a line is drawn parallel to the distant arterial wall. The leading and end measurement points are fixed $10 \mathrm{~mm}$ apart. The IMT measurement is generated automatically - maximum, medium and minimal size, quality index and standard deviation.

Statistical analysis was carried out using the SPSS v.14.0 statistical software (SPSS Inc. Chicago, III). Results were expressed as the mean \pm standard deviation (SD). $\mathrm{P}<$ 0.05 was used as a level of significance of the null hypothesis. We studied the distribution of all continuous data by applying a normality test on the distribution (one-sample KolmogorovSmirnov test). Variation analysis, Student's t-criterion and analysis of covariance (ANCOVA) were used in the statistical analysis.

\section{RESULTS \\ 1. Characteristics of the studied population - age, sex and anthropometric parameters}

There was a statistically significant difference $(\mathrm{p}<$ 
$0.001)$ in the age distribution of patients, carriers and noncarriers of molecular defects. This conclusion was confirmed by the calculated mean age in both patient groups. The mean age of non-carriers was $48.20 \pm 0.47$ years, the mean age of carriers $-45.77 \pm 0.36$ years. There were no statistical differences in the sex distribution in the study sample (ч2 = $0.05 ; p>0.05$ ). We found no statistically significant difference between non-carriers and carriers with respect to body mass index $(25.30 \pm 0.40$ vs $24.63 \pm 0.45$, respectively, $\mathrm{t}=0.50 ; \mathrm{p}>$ $0.05)$.

\section{Molecular biological analysis}

The most common family defect in Apo-B (caused by a substitution mutation at nucleotide position 10780 , which results in replacement of Arg in the defected polypeptide chain by Gln at position 3500) and no mutation of this type was found in the studied population, in patients with total cholesterol above $7.0 \mathrm{mmol} / \mathrm{l}$. The second stage included testing for spot mutations in the LDL-R gene. We screened all 18 exons of the LDL-R gene (apart from the recommended analysis of exons 6,4 and 9) $(11,13,28)$.

\section{Lipid profile in the examined groups}

Total cholesterol and LDL levels were higher in carriers (total cholesterol- $-9.77 \pm 0.49 \mathrm{mmol} / \mathrm{l}$; LDL-C $-7.66 \pm 0.03 \mathrm{mmol} /$ 1) compared to non-carriers (total cholesterol- $8.33 \pm 0.11 \mathrm{mmol} /$ 1; LDL-C-6.55 $\pm 1.77 \mathrm{mmol} / \mathrm{l})$, but the difference between them did not reach statistical significance. Lower HDL-cholesterol levels were found in carriers (HDL- $0.90 \pm 0.03 \mathrm{mmol} / \mathrm{l}$ ) compared to non-carriers (HDL- $1.03 \pm 0.20 \mathrm{mmol} / \mathrm{l}$ ), the difference also not reaching statistical significance. There was not a statistically significant difference in level of triglycerides between carries $(1.45 \pm 0.40 \mathrm{mmol} / \mathrm{l})$, and non-carriers $(1.40 \pm$ $0.30 \mathrm{mmol} / \mathrm{l})(\mathrm{p}>0.05)$. The cholesterol $\mathrm{x}$ years.score was significantly higher in the carries $(440.36 \pm 0.25 \mathrm{mmol}-\mathrm{y} / \mathrm{L})$, than in the non-carries $(390.30 \pm 0.07 \mathrm{mmol}-\mathrm{y} / \mathrm{L})$.

\section{non-carriers}

\section{IMT of the common carotid artery in carriers and}

We found a significantly higher carotid IMT (min,max,mean) in the carriers vs. non-carriers $(\mathrm{p}<0.05)$ (Table 1). This significant difference was confirmed after adjustment for age and gender $(\mathrm{p}<0.05)$ (Table 2).

Table 2. Intima-media thickness of the common carotid artery in the examined groups

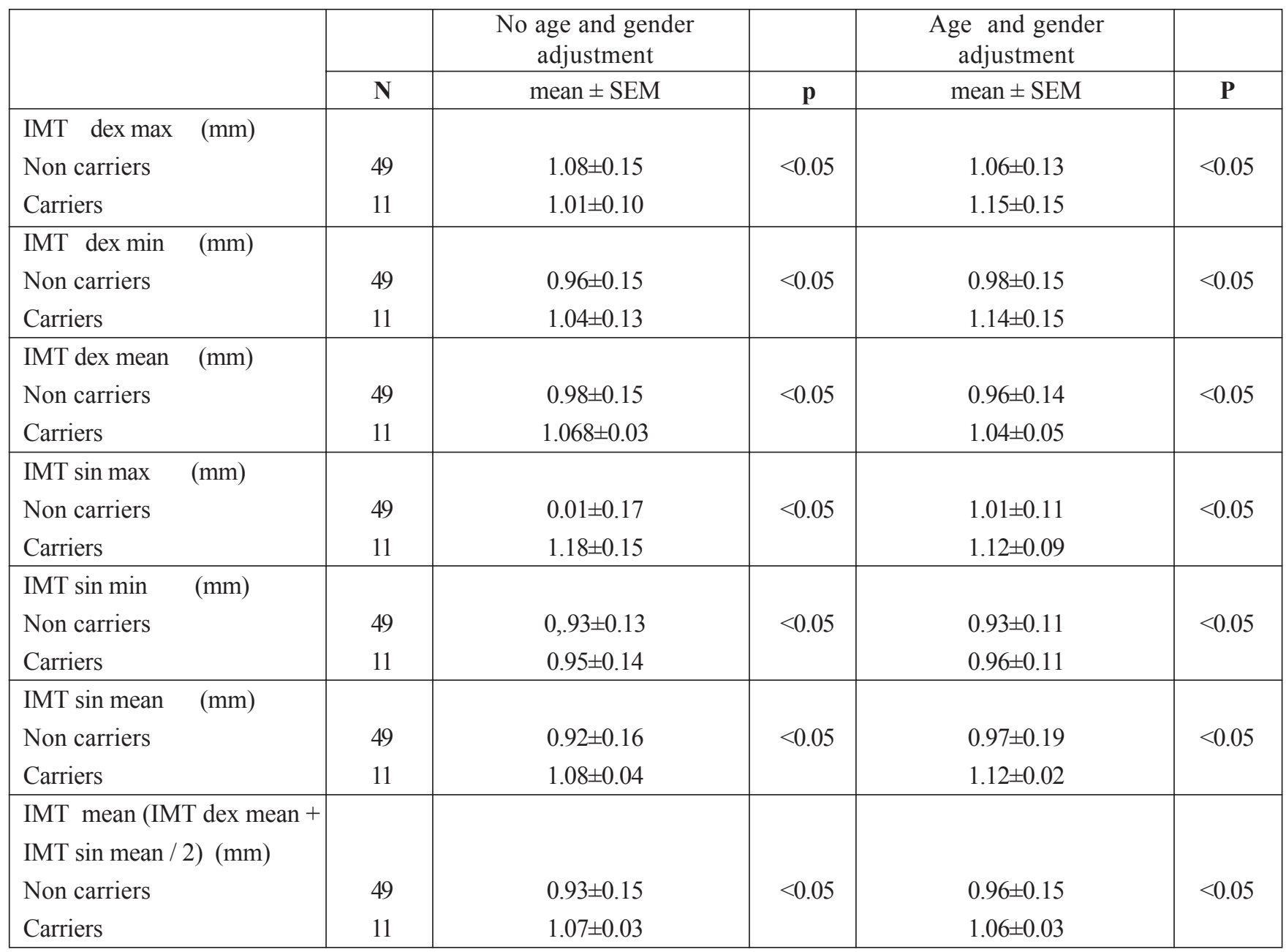




\section{DISCUSSION}

The major findings of the present study are that carotid IMT is significantly higher in carriers of the LDL-R defective gene vs. non-carriers.

The serum cholesterol (total cholesterol and LDL-C) levels of individual carriers of molecular defects (spot mutations of LDL-R) vary within large ranges and are similar to those in severe hypercholesterolemic patients with no defects. This shows that it is impossible to determine which patients should be referred to molecular-biological analysis for spot mutations LDL-R solely on the basis of the lipid parameters. These results are consistent with the results of other studies that refute the thesis that lipid profiles can be informative for screening of patients (11-14). As a matter of fact, the cholesterol-years score, a measure of the lifetime cholesterol levels evaluated by the product of age with cholesterol level is considered as the parameter, which is best correlated to IMT and cardiovascular disease occurrence in FH subjects.

In our study we examined the IMT in carriers and noncarriers of spot mutations in LDL-R gene in patients without other cardiovascular risk factors. Most of the studies have examined IMT in FH and non-FH patients with additional cardiovascular risk factors $(4,5,8)$. In the examined by us patients with severe hypercholesterolemia and familial history of premature cardiovascular disease we found that the patients with spot mutations of LDL-R have a significantly higher carotid IMT in comparison to the noncarriers (Table 1). These data are consistent with reports of other authors. Multiple genes in pathways of production or methabolism of lipids and lipoproteins have been examined in relation to carotid atherosclerosis (13). In the literature IMT is consistently higher and plaques more frequent in $\mathrm{FH}$ patients, but specific mutations have not consistently been implicated (4-7).

It should be borne in mind that it is possible to increase the number of patients harboring the molecular defect affecting results/importance and therefore conclusions regarding lipid parameters.

\section{CONCLUSION}

Our data demonstrate that carriers of the LDL-R defective gene have a higher carotid IMT than non-carriers with newly detected severe hypercholesterolemia. There wasn't found difference between the groups in the respect to the level of lipid parameters.

\section{REFERENCES:}

1. Marks D, Thorogood M, Neil HA, Humphries SE. A review on the diagnosis, natural history and treatment of familial hypercholesterolemia. Atherosclerosis 2003; 168(1):1-14.

2. Poredos P. Intima-media thickness: indicator of cardiovascular risk and measure of the extent of atherosclerosis. Vasc Med 2004; 9(1):46-54.

3. Jerrard-Dunne P, Markus HS, Steckel DA, Buehler A, von Kegler S, Sitzer M. Early carotid atherosclerosis and family history of vascular disease. Arterioscler Thromb Vasc Biol 2003;23(2):302-306.

4. Descamps OS, Gilbeau JP, Leysen $\mathrm{X}$, Van Leuven F, Heller FR. Impact of genetic defect on atherosclerosis in patients suspected of familial hypercholesterolemia. Eur J Clin Invest. 2001;31(11):958-965. Epub 2008.

5. Zannad F, Benetos A. Genetics of intima-media thickness. Curr Opin Lipidol 2003;14(2):191-200.

6. Liao YC, Lin HF, Rundek T, Cheng R, Guo YC, Sacco RL, Juo SH.. SegmentSpecific Genetic Effects on Carotid IntimaMedia Thickness: The Northern Manhattan Study. Stroke. 2008; 39(12):3159-3165.

7. Zhao J, Cheema FA, Bremner JD,
Goldberg J, Su S, Snieder H, et al. Heritability of Carotid Intima-Media Thickness: A Twin Study. Atherosclerosis. 2008;197(2):814-20.

8. Juo SH. Genetics of carotid atherosclerosis. Front. Biosci. 2009; 14: 4525-4534.

9. Lloyd-Jones O, MacRae CA, Wilson PW, Polak JF, Thomas CJ, Wang J, Nam BO, D“Agostino R, Wolf RA, Donald M. Coronary Heart Disease: The Framingham Heart Study Carotid Intima-Media Thickness Is Associated With Premature Parental Coronary Heart Disease: The Framingham Heart Study. Circulation 2003; 108;572-576;

10. Lorenz MW, Markus HS, Bots ML, Rosvall M, Sitzer M. Prediction of clinical cardiovascular events with carotid intimamedia thickness: a systematic review and meta-analysis. Circulation. 2007; 115(4): 459-467.

11. Ganev VS. Mollecular genetic heterogeneity of the predisposition to atherosclerosis in Bulgaria. [PhD Thesis]. Medical University, Sofia 2003; 68-70 (in Bulgarian)

12. Boev T, Kitova L, Kirov S, Ganev $\mathrm{V}$. Genetic heterogeneity of the LDLR gene in patients with hyperlipidemia and clinically manifested ischemic heart disease. Bulgarska Cardiologia 1998;4:27-32 (in Bulgarian)

13. Horvarth AD. Mollecular heterogeneity of LDLR and Apo B genes in healthy people and in patients with hypercholesterolemia in Bulgaria. [PhD Dissertation]. Medical University, 2001; Sofia 68-9 (in Bulgarian).

14. Mihaylov VA, Horvarth AD, Savov AS, Kurshelova EF, Paskaleva ID, Goudev AR, et al. Screening for point mutations in the LDL receptor gene in Bulgarian patients with severe hypercholesterolemia. J Hum Genet 2004;49(4):173-176.

15. Петрова Ю, Маринчев А, Стайков И. Оценка на дебелината на интима-медия - възможности за ранна оценка на АСта Медицински преглед 2004; 2:28-33. (in Bulgarian)

16. Simova I, Denchev S. Endothelial functional and structural impairment in patients with different degree of coronary artery disease development. Heart Vessels. 2008;23(5):305-15.

17. Христова К. Василева Е. Сърдечна функция и каротиден кръвен ток при мозъчносъдова болест. Наука кардиология, 2005, VI, 211-213 (in Bulgarian)

18. Титянова Е., Велчева И., Каракъ- 
нева С., Димитров Н., Христова К. Дамянов П., Димова Р., Попов П., Рамшев К. Каротидна патология и рискови фактори за мозъчно- съдова болест: корелативни клинични, невросонографски и ехокардиографски проучвания. Невросонография и мозъчна хемодинамика, 2007; 3:77-85. (in Bulgarian)

19. Станева МСт, Стайков Ив, Гадева Св, Карамфилов К, Димитров Н, Чирков Ал. Дебелина интима-медия на екстракраниалните каротидни артерии при болни с и без исхемична болест на сърцето. Диагностичен и терапевтичен ултразвук 2005; 1:42-48. (in Bulgarian)

20.Станева МСт, Петров И, Карамфилов К, Димитров Н, Чирков Ал. Честота на екстракраниалната каротидна патология при болни с исхемична болест на сърцето. Българска кардиология 2006; 1:21-25. (in Bulgarian)

21. Vladimirova-Kitova L, Terzieva D, Marinov B. Intima-media thickness and flow-mediated vasodilation in asympto- matic subjects with newly detected severe hypercholesterolemia. Echocardiography 2009;26(9): 1060-1068.

22. Vladimirova-Kitova LG, Deneva TI, Angelova E, Bichev AN, Nikolov FP Role of some biomarkers of atherogenic risk in the screening for molecular defects in the low density lipoprotein receptor in severe hypercholesterolemia. Folia Med. 2008; 50(3):14-22.

23. Vladimirova-Kitova LG, Deneva T, Marinov B. Predictors of the intima-media thickness of carotid artery in asymptomatic newly detected severe hypercholesterolemic patients. Clinical Physiology and Functional Imaging. 2010;30(4):250-259.

24. Mortality in treated heterozygous familial hypercholesterolaemia: implications for clinical management. Scientific Steering Committee on behalf of the Simon Broome Register Group. Atherosclerosis. 1999 Jan;142(1):105-12.
25. Mamotte CD, van Bockxmeer FM. A robust strategy for screening and confirmation of familial defective apolipoprotein B-100. Clin Chem. 1993 39(1):118-121.

26. Lombardi P, Sijbrands EJ, van de Giessen K, Smelt AH, Kastelein JJ, Frants RR, Havekes LM. Mutations in the low density lipoprotein receptor gene of familial hypercholesterolemic patients detected by denaturing gradient gel electrophoresis and direct sequencing. J Lipid Res. 1995;36(4):860-867.

27. Pignoli P, Tremoli E, Poli A, Oreste $\mathrm{P}$, Paoletti R. Intimal plus medial thickness of the arterial wall: a direct measurement with ultrasound imaging. Circulation. 1986 74:1399-1406.

28. Bichev S, Vladimirova-Kitova L, Tsekov I. Screening for point mutation in the LDL receptor gene in Bulgarians with severe hypercholesterolemia. 2005; ESHG abstract.

\section{Corresponding author:}

Lyudmila Georgieva Vladimirova-Kitova, MD, $\mathrm{PhD}$

Clinic of Cardiology, University of Medicine,

2 Alexander Eksarch Str., Plovdiv 4000, Bulgaria

Tel: +359 32 652524, Fax: +359 32 602504;

E-mail: kitov@vip.bg 